\title{
Cordonnier Grade 2 Bacterial Complication Requiring Inpatient Management
}

National Cancer Institute

\section{Source}

National Cancer Institute. Cordonnier Grade 2 Bacterial Complication Requiring Inpatient Management. NCI Thesaurus. Code C138295.

Any bacterially-focused infection requiring treated as an inpatient. 